\title{
Land reclamation, farm mechanisation, rural repopulation: the shifting landscape of the Gharb Valley in Morocco, 1912-1956
}

\author{
Michele Tenzon ${ }^{1,1}$ \\ ${ }^{1}$ Université libre de Bruxelles, Faculty of Architecture La Cambre-Horta, HABITER Study Center, \\ Brussels, Belgium
}

\begin{abstract}
This article investigates rural resettlement schemes implemented by the French colonial administration in the light of the relationship between major economic, social and demographic dynamics in the Protectorate of Morocco. It explores the ways in which the French colonisers transformed the rural landscape of the Gharb valley in Morocco's Rabat region. I depict the spatial configuration of the several stages by which rural colonisation and agricultural modernisation took place in the region, in relation to the patterns of human settlement they produced. The initial spatial configuration of the Gharb, determined by French colonial policies through the official colonisation programme and its orientation toward extensive agriculture, was subverted by the massive introduction of water drainage and irrigation infrastructure. The construction of reservoir dams and the establishment of drainage and irrigation perimeters across the valley induced a concentration of private and public investments that led to rural modernisation in certain, delimited areas. To compensate for a rural exodus that was overcrowding the outskirts of major Moroccan urban centres and for the lack of a local workforce available for employment on colonists' farms, the French architect and urban planner Michel Écochard and his collaborators at the Service de l'Urbanisme conceived an ambitious programme of rural resettlements in the Gharb valley.
\end{abstract}

\section{The "pacification" of Morocco and the French urban and rural colonisation}

In 1906, the Treaty of Algeciras authorised Europeans to buy land in the Moroccan territory, and the Treaty of Fez in 1912 established a French and Spanish Protectorate over the former Moroccan Sultanate. These two treaties set in motion dramatic changes in the territorial structure of the country. A concentration of investments in the coastal cities and their ports, especially in the urban corridor of Casablanca, Rabat and Port Lyautey, determined a rapid urbanisation driven by the exporting of goods to France and elsewhere in Europe.

Overall, the country experienced considerable population growth, from

\footnotetext{
${ }^{1}$ Corresponding author: michele.tenzon@ulb.ac.be
} 
approximately 4 million people in 1912 to about 10 million in 1956 . The growing export volume of Casablanca's harbour and the expansion of the industrial sector attracted workers from the whole country, while the modernisation of agriculture in certain rural areas generated other internal migratory movements [1]. These aspects of the changing demographic dynamics of the Moroccan population were often connected to the distribution of the settlers in both the urban and rural contexts.

Along with the scientific literature produced by historians, geographers and anthropologists on the urbanisation phenomenon in the French Protectorate [2], scholars have described the series of projects by architects and urban planners that aimed to alleviate the housing crisis arising from the rapid population growth and ruralto-urban migration [3, 4]. In particular, the work of Michel Écochard gained acclaim for its use of modernist planning, architectural ideas and modern technology to conceive and build an "urbanisme pour le plus grand nombre" (urbanism for the masses) [5].

In parallel with the concentration of the French presence along the Atlantic coast, colonial resident-general Hubert Lyautey embarked on his project of the "pacification" of Morocco through a combination of two actions: military penetration and the strategic occupation of local markets in the country's internal areas. French ideas on modern warfare, which had been elaborated in earlier colonial endeavours in Madagascar and Indochina, entailed the stabilisation of a French presence in rural as well as urban areas in order to consolidate the military occupation of the country and foster the modernisation of the countryside [6]. Hence, from the earliest phases of the Protectorate on, measures were taken to facilitate the settlement of French colonists along lines of penetration, moving especially from the coast towards the central regions of the country.

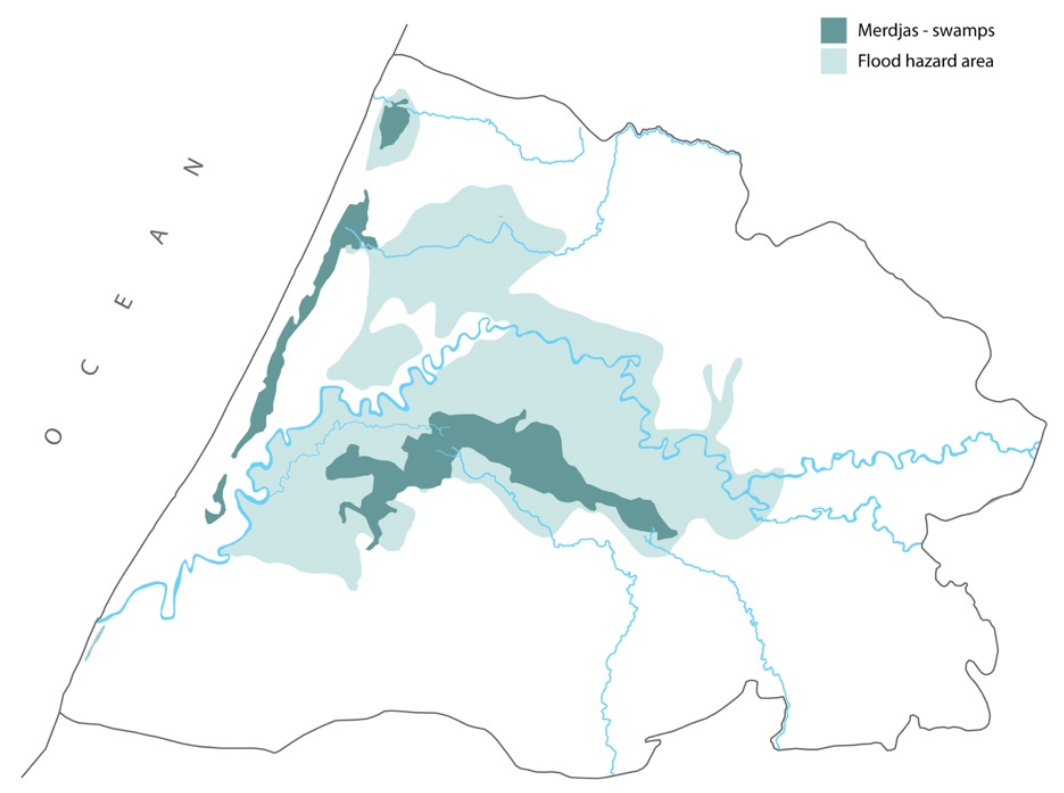

Fig. 1. The Gharb valley: hydrography (Source: the author)

The Gharb valley, a coastal plain in northeast Morocco, was one of the first rural areas where colonists settled (Fig. 1). The plain is delimited on its south by the Mamora, a cork oak forest, and on the east and north by the Rif and Middle Atlas Mountains. It is traversed by the Sebou River, which gathers waters from both the mountain chains. 
At the mouth of the Sebou, French colonial administrators founded the new town of Port Lyautey, now known as Kenitra. The region's significance was connected to its strategic location between the coastal poles of Rabat and Casablanca and the inland imperial cities of Meknes and Fez. Even today, the route from Rabat to Fez to Oujda is the only railway connection between the east and west sides of the country. Moreover, the Gharb's richness in water and the presence of a dark type of soil called tirs, which was believed to owe its colour to a high percentage of organic matter, triggered extraordinarily optimistic speculations about the possibilities that establishing modernised agriculture operations in the region might offer to French settlers. Over time, many of those rosy predictions proved to be unrealistic, but the series of partially implemented projects, failed attempts and ambitious resettlement schemes conceived for the area left profound traces that continue to affect the region's development even today.

\section{Modernisation and repopulation strategies in the Gharb valley}

Clearing and levelling of land in the Gharb valley began in the early years of the French occupation. Anti-malaria measures included clearing the banks of canals and the construction of concrete wells. Some initial drainage works were also completed, albeit on a small scale and often with poor results, as in the case of the Compagnie du Sebou, a private consortium that received a concession in 1919 to drain two large plots of land totalling almost 10,000 hectares. The consortium failed less than 10 years later when a flooding event ruined the entire harvest, demonstrating the need for a bettercoordinated effort to modify the hydraulic conditions of the area [7].

Indeed, the landscape of the valley was profoundly affected by the highly irregular water regimes of the Sebou River and its main tributaries. The seasonal fluctuations of precipitation levels caused droughts during the dry season and frequent floods in the rainy months, primarily December and January. The region's topography combined with the effects of flooding generated large wetlands called merdjas, the size of which varied considerably according to the season and the annual climatic conditions. The largest of those merdjas occupied the central part of the region and resulted primarily from the overflowing of the Oued Beth, the main affluent of the Sebou in its terminal section. A second swamp was located in the western part of the valley, behind a ridge of dunes that runs parallel to the coast, blocking access to the ocean.

Native Moroccans' settlements in the region were clustered along the areas less subject to flooding, where the soil was more fertile. However, the region's hydrography had never allowed the creation of large centres in the lower parts of the valley; these areas were inhabited mainly by semi-nomadic populations who practised both breeding and agriculture.

The native populations lived in so-called nouala, huts built with reed and clay and arranged in douars, a term still used today in the toponymy of rural settlements in Morocco.

The arrival of the first colonial settlers in the Gharb proceeded in conjunction with the construction of the first railway lines that crossed the valley. Indeed, the first concessions of land and the first service centres for French colonists, such as Sidi Yahia, Sidi Slimane, Petitjean (present-day Sidi Kacem), Mechra Bel Ksiri and Souk el Arbaa du Gharb, were located along the Port Lyautey-Fez and Fez-Tanger railway branches.

The secluded character of the spatial configuration of French rural colonisation in the Gharb valley accentuated territorial disparities. French colonists clustered in the 
areas that were better connected with mobility infrastructure and where investments had been made to improve soil productivity and quality of life. On the other hand, native populations were often relegated to smaller and less profitable areas and benefitted far less from the infrastructural sanitary and economic improvements financed by the colonial administration during the first decades of the Protectorate.

\section{Water, infrastructures and rural modernity: the Service de l'Urbanisme in the Gharb}

The Gharb valley was one of the first areas where conspicuous investments were made to foster a switch from dry farming to agriculture based on permanent irrigation. An irrigation perimeter of about 30,000 hectares was established in the Petitjean area; later, a drainage perimeter was delimited along both the right and left banks of the Sebou River [8].

The functioning of the Petitjean irrigation perimeter was based on two infrastructure elements: the El Kansera reservoir dam, built in a narrow gorge where the Beth River flows, and a network of primary, secondary and tertiary canals that served to divert water from the river by means of a diversion dam and to bring it to previously nonirrigated land (Fig. 2).

The El Kansera dam, completed in 1936, functioned as a regulator of the river's water regime. It stored water in a reservoir during the rainy season, thereby preventing the violent floods that frequently affected the region, and regularly released water during the dry season to ensure the availability of water for irrigation.

The Sebou drainage perimeter consisted of a system of canals that drained water from the merdjas and from areas subjected to flooding and then carried it into the Sebou River or directly to the Atlantic Ocean. Due to the large area covered by the perimeterbetween 200,000 and 250,000 hectares needed to be reclaimed, of which 30,000 hectares were permanently flooded-the work advanced progressively by compartments and lasted for several decades. Indeed, when the French Protectorate was relinquished, much of the hydraulic work was still incomplete; it continued long after Morocco gained its independence under the guidance of the United Nations Food and Agriculture (FAO) and the World Bank [9].

Over the decades, thousands of hectares of merdjas were drained although, because of the difficulty of regulating the Sebou River's regime, flooding events still occurred occasionally; even today, the region is considered relatively flood-prone.

The lower parts of the valley were crossed by a network of rectilinear canals lined with concrete; the geometry of these canals was rigidly defined by the topography and the need to minimize water pumping. Besides the reservoir and diversion dams, other water-related infrastructure included water bridges and siphons as well as aboveground canals.

At a finer scale, irrigation works implied a complex renegotiation and redesign of property boundaries. Although alienation of state-owned land and re-allotment of landholdings were practised even during the official colonisation period, hydraulic works operated on a wider level and on larger portions of the valley. As a consequence of the incorporation of the customary land tenure system into the newly defined, modern and formal colonial law, the recognition of existing land-related rights, the compilation of a land register, and procedures for the expropriation and redistribution of land added up to a major effort that kept the local rural engineering department heavily occupied.

At the regional scale, the integration of the new infrastructure system into the current territorial structure produced a wider redefinition of the spatial and functional 
relationship between the existing and newly created rural centres. The redefinition of the physical landscape and the reorganisation of property boundaries were intertwined with issues related to the region's demography.

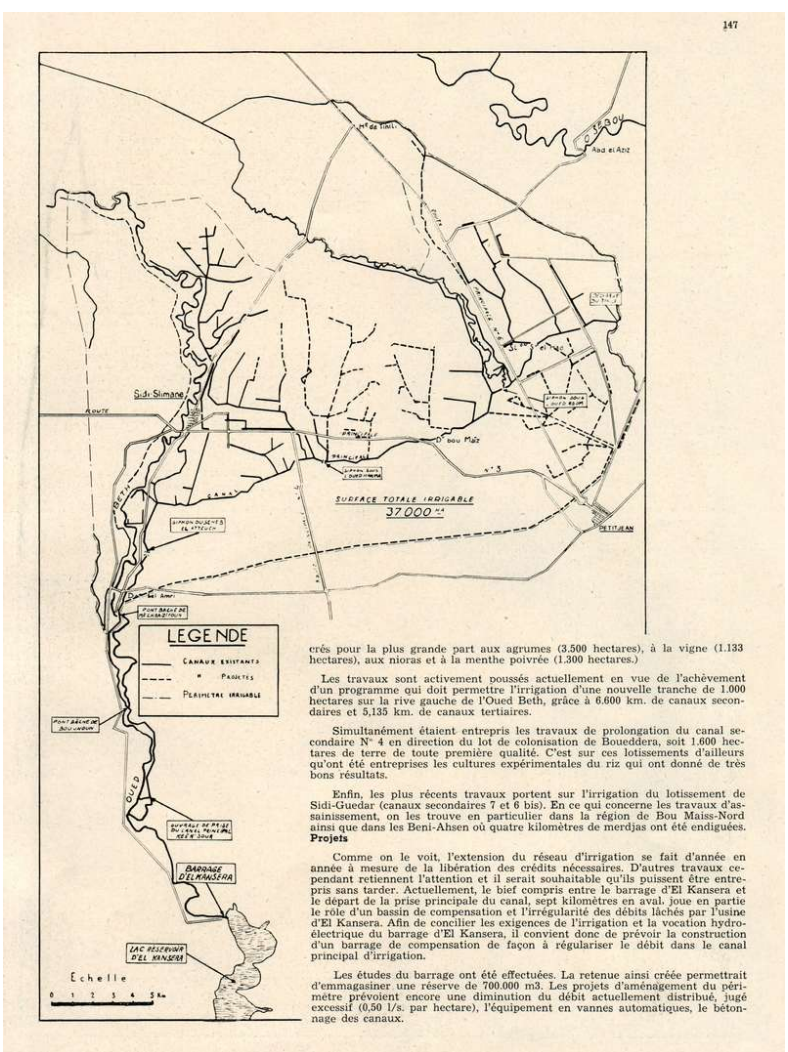

Fig. 2. The Petitjean irrigation perimeter [13].

Since the earliest decades of the French presence in Morocco, the concentration of investments in the coastal cities had caused internal migration phenomena. Major urban poles on the Atlantic coast attracted people from the countryside; together with the natural increase of the urban population, this influx created severe overcrowding problems and the emergence of shanty-towns on the outskirts of the cities and in proximity to harbours and industrial areas.

The two interrelated phenomena of rural exodus and uncontrolled urban growth have been widely described at the national level by urban geographers, sociologists and architectural historians $[10,11,12]$. Repopulation strategies in the Gharb had the joint aims of decentralising industrial production and alleviating the problem of urban overcrowding by limiting the rural exodus. Indeed, decentralisation and demographic balancing were two main declared objectives of Michel Écochard's seven-year tenure as head of the Service de l'Urbanisme. At the beginning of the 1950s, a team guided by Écochard conceived a series of rural resettlement schemes aimed at recomposing the fragmented landscape that the various stages of native and colonial appropriation of the Gharb valley had created.

The water infrastructure of the irrigation and drainage perimeters provided a framework on which the resettlement schemes were based. The reclaimed wetlands and the underexploited land were seen as opportunities to expand rural modernisation 
to a larger portion of the region. Even though drainage and irrigation works were still far from complete in most of the valley, Écochard's collaborators foresaw the possibility of achieving a quick repopulation of the region through the provision of public facilities and rationalisation of the settlement organisation.

The Service de l'Urbanisme conceived a network of rural settlements hierarchically organised according to a central-place or Christallerian model. Three settlement categories were distinguished: primary, secondary and tertiary. Primary centres were small agro-industrial cities with the capacity to attract a diversified set of industries so to attract workers and decentralise the workforce that had been flocking to major cities. Secondary centres were essentially conceived as service locations that would supply the dispersed network of rural villages, or tertiary settlements.

A series of surveys was completed to map the distribution of the Moroccan population in the Gharb and to detail the complex scenario of landholdings and property types that characterised the area outside the big colonial farms. The detailed study of the settlements' location, size and function was carried out in collaboration with the Génie Rural, the rural engineering office that was also responsible for the structural redefinition of the area's agricultural production [14].

Features such as access to potable water, the availability of land to be assigned to the native population, and the soil's productivity, together with the conditions imposed on land use by the drainage and irrigation infrastructure, became the main criteria for the distribution and characterisation of the settlements.

When one examines the model plans conceived by the Service de I'Urbanisme or the many sketches produced by Écochard's collaborators, including Elie Mauret, the networked nature of the proposed settlements becomes explicit through their relationship with the existing or planned mobility infrastructure (Fig. 3).

The schemes proposed to regroup the existing native settlements into larger villages equipped with basic public facilities and located along a road. Although the number and the nature of the public buildings and the size of the public spaces varied according to the importance of the settlements, some recurring elements can be observed.

Residential areas were separated from the main road crossing the settlement, often by means of strips of land up to 50 metres wide and covered with trees as high as 50 metres tall. In contrast, public facilities and squares were open to the road, suggesting a continuity between infrastructure and public space (Fig. 4). Large parking lots were planned in proximity to the souks-that is, the areas, often protected by walls, where the weekly open-air markets took place.

Public spaces and residences were often located on the concave side of a curved road or delimited by two roads. Where a village was located on a straight road, residential and public areas were located sequentially along the road and a second, parallel service road was created behind the buildings to permit movement within the settlement. For traffic-related reasons, access to the souk and main square was situated far away from major intersections and also separated from the traffic flow headed towards the private residencies (Fig. 5, 6). 


\section{BHWMIENTS JWE COMPOSITION \\ J'UN CWN'Tli RURAI,}

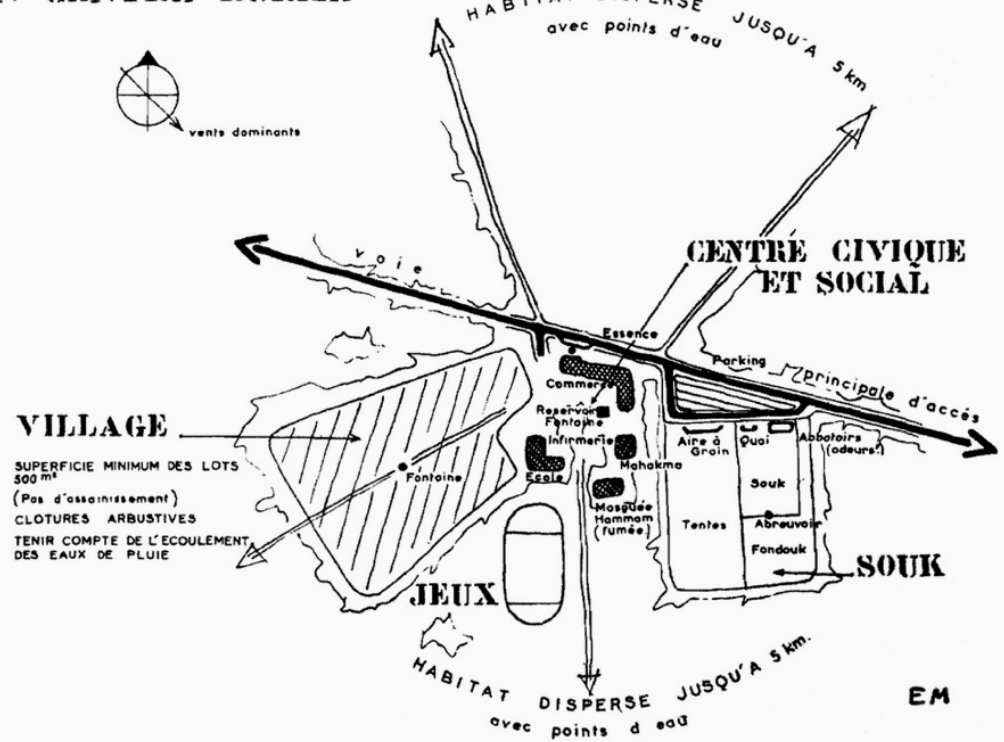

Fig. 3. Model plan for a rural centre [1].

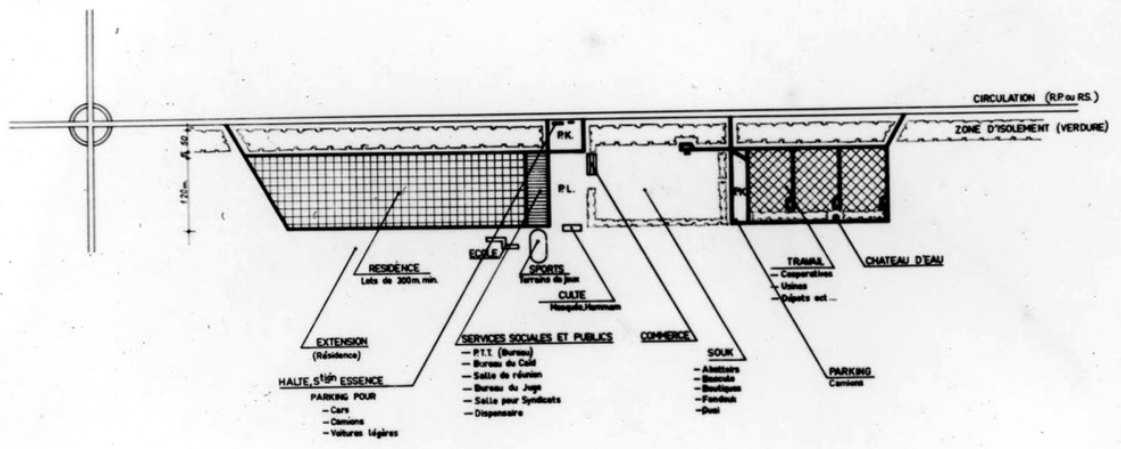

Fig. 4. Model plan of a rural chief town.

Source: Photothèque École Nationale d'Architecture, Rabat.

\section{Conclusions}

Early French colonial settlements in the Gharb, as well as the resettlement schemes of the 1950s, demonstrate the existence of a relationship between the French repopulation policies, rural modernisation and colonial strategies for the extraction of resources. The purchase of landholdings by private French organizations and the expropriations in favour of colonising farmers would work in tandem with engineering projects and the provision of public facilities to further widen the gap between the modern and the traditional agricultural sectors.

The resettlement schemes conceived by the Service de l'Urbanisme were intended, in the words of Écochard and his collaborators, as means to narrow this gap and to 
improve the living conditions of native populations. However, the actions aimed at limiting the rural exodus and stabilising the presence of a Moroccan workforce in proximity to the land that now belonged to Europeans should also be understood as designed to preserve colonial domination over the region.

These examples of urban planning, the vision of modernity they proposed, and the public and domestic space they produced should therefore be interpreted both as triggers of rural development and as a reassertion of forms of social and economic subjugation of the colonised society.
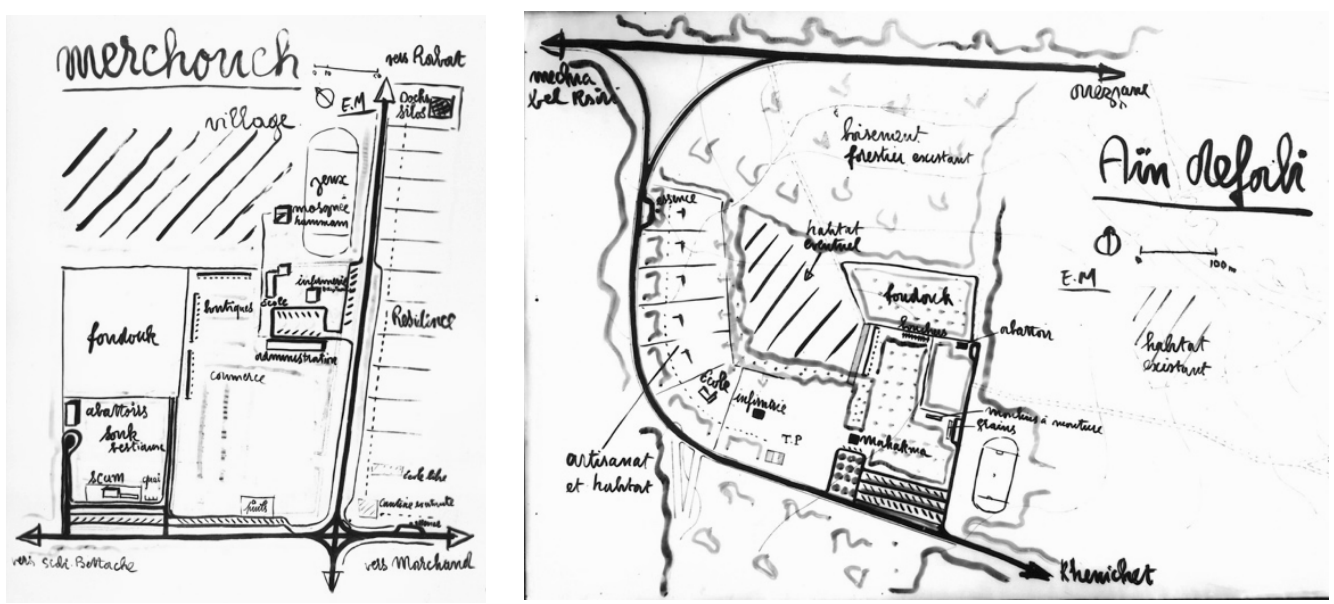

Fig. 5, 6. Sketches of the plans of Merchouch and Ain Defali [15].

\section{Acknowledgement}

MODSCAPES is a collaborative research project funded under the HERA - Humanities in the European Research Area 3rd Joint Research Program dedicated to "Uses of the Past" (20162019). This project has received funding from the European Union's Horizon 2020 research and innovation program under grant agreement $n^{\circ} 649307$.

\section{Short Resume}

Michele Tenzon holds a Master degree in Architecture from the University of Ferrara, Italy and in Architectural History and Theory from the Bartlett School of Architecture, University College of London. He is currently Ph.D. Fellow at the Université libre de Bruxelles, Faculty of Architecture La Cambre-Horta. His current research work deals with rural development and resettlement schemes implemented in Morocco in the colonial and post-colonial period.

\section{References}

1. FORICHON R.; MAS, P. 1958. "Les problèmes de la répartition du peuplement au Maroc", Bulletin Économique et Social du Maroc, vol. 21, n 76: 471-506.

2. GERSHOVICH, M. 2000. French Military Rule in Morocco: Colonialism and its Consequences, London, Frank Cass.

DOI https://doi.org/10.4324/9780203044988

3. WRIGHT, G. 1991. The Politics of Design in French Colonialism, Chicago 
University Press.

4. COHEN, J.L.; ELEB, M. 1998. Casablanca: mythes et figures d'une aventure urbaine, Paris, Hazan.

5. ÉCOCHARD, M. 1950. "Urbanisme et construction pour le plus grand nombre", Annales de l'Institut Technique du Bâtiment et des Travaux Publics, $\mathrm{n}^{\circ} 148$.

6. LEROY A. 1922. "L'agriculture", in H. Avelot et al., La renaissance du Maroc: dix ans de Protectorat (1912-1922), Rabat, Résidence Générale de la République Française au Maroc.

7. LE COZ, J. 1964. Le Rharb: fellah et colons. Une étude de géographie régionale, Rabat.

8. L'Équipement hydraulique du Maroc (1954), Rabat, Société d'Études Économiques Sociales et Statistiques du Maroc.

9. PERENNES, J. J. 1993. L'eau et les hommes au Maghreb: contribution à une politique de l'eau en Méditerranée, Paris, Karthala.

10. JOHNSON, K. M. 1972. Urbanisation in Morocco: An International Urbanization Survey Report to the Ford Foundation.

11. S. BENZAKOUR, S. 1978. Essai sur la politique urbaine au Maroc, 1912-1975, Casablanca, Éditions maghrébines.

12. DETHIER, J. 1970 "Soixante ans d'urbanisme au Maroc", Bulletin Économique et Social du Maroc, $\mathrm{n}^{\circ}$ 118-119: 5-59.

13. GIRARD (ed.). 1951. L'hydraulique et l'électricité au Maroc.

14. MAURET, E. 1954. "Problèmes de I'habitat dans la région de Rabat", Bulletin Économique et Social du Maroc, vol. 18, n.64, pp. 587-600.

15. MAURET E.; POMMERET, H.; RINGUELET. R. 1956. "Mise en valeur et équipement rural de la région de Rabat", Bulletin Économique et Social $d u$ Maroc, vol. 20, $\mathrm{n}^{\circ}$ 69: 15-70. 